\title{
PELATIHAN PEMBUATAN PERMEN JELLY JAHE DALAM KEMASAN UNTUK MENINGKATKAN IMUN TUBUH DI RW 02 DUREN SAWIT, JAKARTA TIMUR
}

\author{
${ }^{1 *}$ Ridawati, ${ }^{2}$ Alsuhendra \\ Universitas Negeri Jakarta, DKI Jakarta, Indonesia \\ Email : *ridawati@unj.ac.id
}

\begin{abstract}
Manuskrip: Desember -2021; Ditinjau: Desember -2021; Diterima: Desember -2021; Online: Januari-2022; Diterbitkan: Januari-2022
\end{abstract}

\begin{abstract}
ABSTRAK
Kegiatan dengan judul "Pelatihan Pembuatan Permen Jelly Jahe dalam Kemasan untuk Meningkatkan Imun Tubuh di RW 02 Duren Sawit, Jakarta Timur" merupakan salah satu kegiatan pengabdian kepada masyarakat yang didanai dari dana BLU POK Fakultas Teknik. Kegiatan ini bertujuan untuk meningkatkan pengetahuan masyarakat Kelurahan Duren Sawit, khususnya RW 02. Kegiatan yang direncanakan dalam masa pandemi covid-19 juga ditujukan untuk menambah pengetahuan masyarakat untuk meningkatkan imunitas dengan cara mengonsumsi produk yang mengandung senyawa fungsional seperti jahe, Kegiatan diawali dengan penyusunan proposal kegiatan, diskusi program kegiatan, survei lokasi kegiatan, pengurusan kemitraan, persiapan bahan, pelaksanaan dan analisis data serta pelaporan. Pelaksanaan dilakukan selama 4 bulan dari bulan Juni hingga September 2021. Jumlah khalayak sasaran strategis yang hadir pada kegiatan ini adalah 31 orang. Kegiatan dilakukan dengan metode ceramah, demonstrasi dan diskusi. Ceramah dilakukan oleh tim pelaksana kegiatan P2M. Setelah pelaksanaan peserta diminta untuk mengisi angket untuk mengetahui tingkat pengetahuan dan sikap sasaran terhadap produk permen jelly jahe. Hasil kegiatan menunjukkan peningkatan pengetahuan dan ketrampilan peserta dalam membuat permen jelly jahe. Peserta sangat antusias untuk mempraktekkan dan memproduksi permen jelly jahe.
\end{abstract}

\section{Kata Kunci: Permen Jelly, Jahe, Imun, Pelatihan}

\section{PENDAHULUAN}

Pada masa pandemi Covid-19 seperti sekarang ini, setiap orang harus mampu menjaga kesehatan agar tidak tertular virus. Masyrakat perlu menyiapkan makanan khusus untuk meningkatkan imun tubuh di masa pandemi virus corona Covid-19 seperti sekarang ini, termasuk makanan jajanan.

Pandemi Covid-19 menyebabkan banyak perubahan dalam kehidupan seharihari masyarakat. Makanan yang mengandung zat gizi yang baik sangat penting dikonsumsi sebelum terjadi infeksi, selama infeksi dan bahkan setelah sembuh dari infeksi virus. Infeksi virus menyebabkan tubuh korban deman, sehingga tubuh 
memerlukan tambahan energi dan zat gizi yang cukup. Menjaga pola makan dan pemberian makanan jajanan bagi keluarga dan terutama anak-anak penting untuk diperhatikan. Menjaga jenis makanan yang dikonsumsi oleh keluarga dan masyarakat sangat penting selama masa pandemic Covid-19.

Kegiatan pelatihan melalui kegiatan pengabdian pada masyarakat memiliki peranan untuk meningkatkan kualitas sumber daya manusia. Masyarakat yang tidak memiliki kompetensi keahlian merupakan salah satu penyebab meningkatnya angka pengangguran, karena tidak memiliki keahlian sehingga tidak bisa produktif sendiri. Untuk itu diperlukan keahlian tertentu yang dapat diperoleh dari berbagai kegiatan pelatihan.

Kegiatan pengabdian pada masyarakat merupakan salah satu cara untuk dapat menyebarluaskan ilmu dan teknologi pada masyarakat. Penyebaran ilmu dan teknologi dari akademisi diperlukan agar ilmu dan teknologi tersebut dapat bermanfaaat bagi masyarakat. Bentuk kegiatan yang dapat dilakukan adalah kegiatan pelatihan dan penyuluhan. Kegiatan ini diharapkan dapat memberikan dukungan penuh untuk pembangunan terutama untuk meningkatkan pengetahuan dan ketrampilan masyarakat.

Salah satu kelompok masyarakat yang menjadi sasaran pelatihan ketrampilan adalah ibu-ibu PKK di RW 02 kelurahan Duren Sawit, kecamatan Duren Sawit, Jakarta Timur. Tempat pelatihan direncanakan di Aula TK Ruhul Islam, jalan Ekonomi Raya RW 02 Duren Sawit.

Masyarakat RW 02 Kelurahan Duren Sawit merupakan salah satu masyarakat yang berdomisili di kecamatan Duren Sawit. Kecamatan Duren Sawit terdiri dari 7 kelurahan dengan 95 RW dan 1.103 RT. Pembangunan Banjir Kanal Timur (BKT) juga menyebabkan semakin tergusurnya penduduk asli Kecamatan Duren Sawit, khususnya penduduk yang tinggal di sepanjang proyek pembangunan BKT tersebut. Masyarakat RW 02 kelurahan Duren Sawit merupakan kelompok warga yang tinggal di kiri dan kanan lokasi BKT. Warga masyarakat yang tinggal disepanjang BKT merupakan warga yang bermatapencaharian dengan memanfaatkan lahan pinggir BKT untuk bercocok tanam. Sebagian besar warga adalah pekerja dan pedagang. Pandemi Covid-19 juga sangat berdampak terhadap matapencarian warga.

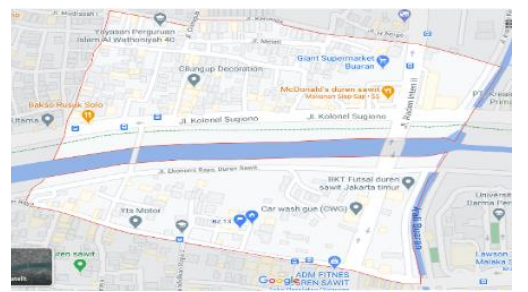

Gambar 1. Peta Wilayah RW 02 Kelurahan Duren Sawit

Dengan berubahnya perilaku kehidupan masyarakat akibat pandemi Covid19 yang sudah berlangsung lebih dari setahun, kesadaran masyarakat akan pentingnya hidup sehat dan menjaga kesehatan tubuh melalui konsumsi bahan makanan yang dapat meningkatkan daya tahan tubuh atau imunitas tubuh juga semakin tinggi. Produksi produk permen jelly jahe merupakan salah satu peluang 
usaha yang dapat dilakukan masyarakat. Usaha bidang ini dapat dijadikan sebagai batu loncatan untuk melakukan usaha lainnya karena produksi permen jelly jahe tidak memerlukan modal yang besar. Modifikasi dan inovasi produk permen ini juga sangat terbuka luas. Usaha permen dengan penambahan rempah adalah salah satu usaha yang dengan mudah dapat dilakukan masyarakat. Dengan kondisi perekonomian seperti ini maka pelatihan minuman bubuk bubuk adalah pilihan variasi yang menarik.

Tujuan kegiatan P2M F:

1. Membuat produk permen jelly yang bermanfaat bagi imunitas tubuh

2. Menciptakan inovasi baru yang bermanfaat bagi masyarakat.

3. Mengenalkan kepada masyarakat bahwa dari rempah, dapat digunakan menjadi sebuah produk yang memiliki nilai jual.

4. Inisiatif wirausaha sebagi pemilik usaha dalam membuka usaha.

5. Menambah pengalaman dan pengetahuan tentang berwirausaha.

6. Dapat membuka lapangan kerja baru di masa pandemi Covid-19

\section{Permasalahan Mitra}

Masyarakat terutama ibu-ibu PKK di RW 02 perlu dilatih untuk meningkatkan pengetahuan dan ketrampilan dalam membuat makanan untuk membantu meningkatkan imunitas tubuh di masa pandemi Covid-19. Permasalahan yang timbul akibat pandemi Covid-19 yang berkepanjangan menuntut masyarakat tetap eksis dan terus berupaya meningkatkan kesehatannya. Salah satu khalayak sasaran yang strategis dalam pelaksanaan kegiatan ini adalah ibu-ibu PKK yang memegang kendali konsumsi dan belanja makanan jajanan bagi anak dan keluarganya. Beberapa permasalahan yang dijumpai pada masyarakat di RW 02 Duren Sawit adalah:

1) Rendahnya pengetahuan tentang pembuatan makanan untuk meningkatkan imunitas tubuh seperti permen jelly jahe yang menarik serta memenuhi syarat yang ditetapkan pemerintah.

2) Kurangnya pemahaman masyarakat tentang peningkatan nilai tambah produk melalui proses pengolahan pangan.

3) Kurangnya upaya untuk meningkatkan pengetahuan dan ketrampilan masyarakat dalam membuat permen jelly jahe yang dapat yang diproduksi.

Kurangnya pengetahuan masyarakat untuk melakukan usaha dalam pengembangan produk untuk meningkatkan imun tubuh.

\section{Solusi Permasalahan}

Alternatif solusi yang ditawarkan untuk mengatasi berbagai permasalahan yang dihadapi oleh masyarakat RW 02 Duren Sawit adalah sebagai berikut:

1. Peningkatan pengetahuan masyarakat tentang produk permen jelly jahe. Luaran dari solusi peningkatan pengetahuan masyarakat adalah artikel yang akan dipublikasikan di jurnal pengabdian pada masyarakat.

2. Peningkatan ketrampilan masyarakat dalam membuat mengolah hasil alam. Luaran dari solusi ini adalah paten permen jelly jahe.

3. Pemberian materi kemasan dan pelabelan kepada masyarakat dengan luaran paten label permen jelly jahe. 
4. Sosialisasi kegiatan pembuatan bubuk sari jahe, dengan luaran video youtube kegiatan pembuatan permen jelly jahe.

Guna mewujudkan 3 solusi yang ditawarkan di atas, sejumlah kegiatan berikut penting untuk dilaksanakan dalam kegiatan pengabdian kepada masyarakat ini. Kegiatan-kegiatan tersebut adalah;

1. Melakukan koordinasi dengan masyarakat RW 02 Duren Sawit untuk mendapatkan izin pelaksanaan kegiatan pengabdian kepada masyarakat di tempat tersebut.

2. Melakukan diskusi dengan masyarakat dan perangkat RW 02 Duren Sawit guna menetapkan metode pemecahan masalah yang dihadapi masyarakat dalam pengembangan kemasan dan label makanan yang baik dan menarik.

Melaksanakan kegiatan penyuluhan tentang berbagai manfaat produk dan bahan baku.

\section{METODE}

\section{Persiapan Pelaksanaan}

Langkah-langkah kegiatan pengabdian yang dilakukan diawali dengan penandatanganan kemitraan dengan Ketua RW 02, dilanjutkan dengan penentuan tempat pelaksanaan, dan koordinasi selanjutnya dilakukan ketika proposal kegiatan telah disetujui untuk dilaksanakan dan telah dilakukan penandatanganan kontrak kegiatan.

Tahapan diawali dengan pengurusan surat kemitraan, penyusunan rencana kegiatan secara rinci sesuai dengan proposal kegiatan, penandatanganan kontrak pelaksanaan. Selanjutnya dilakukan persiapan materi penyuluhan, angket pre-test, post-test dan survey kepuasan pelaksanaan. Uji coba pembuatan produk dilakukan oleh mahasiswa dan selanjutnya dilakukan proses pembuatan video untuk penyuluhan.

\section{Perekrutan khalayak sasaran strategis}

Mitra kegiatan mempersiapkan lokasi kegiatan dan mengundang khalayak sasaran untuk mengikuti kegiatan pelatihan. Kegiatan pelatihan mengundang kader ibu PKK di dari 5 RT di RW 02. Kegiatan perekrutan peserta dilakukan oleh ibu sekretaris RW 02, sekaligus Kepala Sekolah TK Ruhul Islam dengan cara menghubungi dan mengundang peserta untuk mengikuti penyuluhan dan pelatihan.

\section{Pelaksanaan Kegiatan Penyuluhan dan Pelatihan}

Metode yang digunakan dalam pelatihan ini adalah ceramah, demonstrasi dan diskusi. Metode ceramah dilakukan oleh tim pelaksana kegiatan dan dilanjutkan dengan metode demonstrasi proses pembuatan permen jelly jahe. Demonstrasi juga dilakukan secara virtual menggunakan video yang diberikan kepada peserta.

\section{HASIL DAN PEMBAHASAN}

\section{Lokasi dan Tempat}

Kegiatan dilaksanakan di Aula Asma Imaliyah TK Ruhul Islam dengan jumlah peserta khalayak sasaran stategis warga RW 02 Duren Sawit. Waktu pelaksanaan kegiatan pelatihan dilakukan pada hari Kamis, 26 Agustus 2021. 


\section{Bahan dan alat}

Bahan yang digunakan pada kegiatan ini adalah bahan baku utama pembuatan permen yaitu gula pasir, bahan pengenyal yaitu tepung agar-agar atau tepung jelly, dan bahan fungsional yaitu jahe bubuk instan siap pakai. Proses pembuatan dapat dilihat di artikel pelatihan sebelumnya (Ridawati \& Alsuhendra, 2017) atau dapat juga dilihat pada link youtube kegiatan pelatihan : https://www.youtube.com/watch?v=Bdmfclspkjc). Angket pre-test dan post test diberikan untuk memahami peningkatan pengetahuan peserta.

Alat yang digunakan untuk kegiatan pelatihan yaitu alat pembuatan bubuk jahe instan, timbangan atau alat takar, panci untuk memasak dan larutan gula, tepung agar-agar/jelly, dan bubuk jahe. Selain itu dibutuhkan juga wadah untuk pencetakan atau pendinginan adonan permen jelly jahe.

\section{Evaluasi Kegiatan dan Monitoring}

Pelaksanaan kegiatan pengabdian pada masyarakat dievaluasi dengan memberikan angket survey kepada peserta. Monitoring keberlanjutan program dilakukan melalui media sosial dilakukan setelah kegiatan dilaksanakan untuk memantau aplikasi pembuatan produk oleh peserta.

\section{Kegiatan Penyuluhan}

Kegiatan Pengabdian kepada Masyarakat Fakultas Teknik (P2M-F) merupakan kegiatan bagian dari ruang lingkup pengembangan kesejahteraan meliputi pengembangan usaha kuliner. Peserta pelatihan berjumlah 31 ibu PKK RW 02 dari 5 RT yaitu RT 004, 005, 006, 012 dan 013. Kegiatan diawali dengan pembacaan doa dan sambutan oleh Ibu Sekretaris RW 02.

Penyuluhan dilakukan dengan metode ceramah dan diskusi. Pelatihan diawali dengan kegiatan penyampaian materi tentang pentingnya pelatihan pembuatan makanan yang bermanfaat bagi kesehatan tubuh. Pada masa pandemi Covid-19, setiap orang harus mampu menjaga kesehatan agar tidak tertular virus. Masyarakat perlu menyiapkan makanan khusus untuk meningkatkan imun tubuh di masa pandemi virus corona Covid-19, termasuk makanan jajanan. Makanan yang kaya zat gizi sangat penting dikonsumsi sebelum terjadi infeksi, selama infeksi, dan bahkan setelah sembuh dari infeksi virus. Infeksi virus menyebabkan tubuh korban demam, sehingga tubuh memerlukan tambahan energi dan zat gizi yang cukup. Menjaga pola makan dan pemberian makanan jajanan bagi keluarga dan terutama anak-anak penting untuk diperhatikan.

Kegiatan penyuluhan ini memberikan pemahaman yang lebih mendalam terhadap pengetahuan akan pentingnya makanan yang memiliki nilai fungsional tertentu. Penggunaan jahe dalam pengolahan makanan memberikan manfaat fungsional tertentu. Pertanyaan pada angket post test tentang penggunaan rimpang jahe sebagai bahan pengolahan makanan dapat dijawab dengan tepat oleh seluruh peserta $(100 \%)$. Peningkatan jawaban peserta yang benar tentang jahe yang yang dapat meningkatkan daya tahan tubuh atau imun tubuh meningkat dari $24 \%$ menjadi $77 \%$ (Gambar 1). 


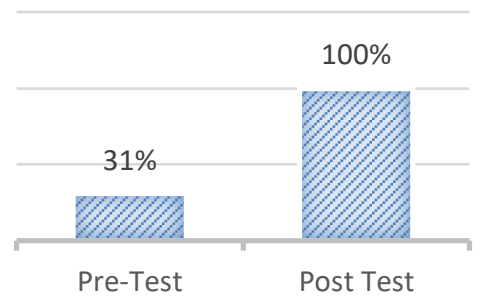

Gambar 2. Pengetahuan Peserta tentang Jahe untuk Meningkatkan Imun

Kandungan senyawa fitokimia yang terdapat didalam jahe secara umum menjadikan jahe sebagai bahan makanan yang dapat meningkatkan imun atau daya tahan tubuh (Mashadi NS et al., 2013). Dilaporkan juga kemampuan jahe sebagai senyawa antioksidan yaitu senyawa yang dapat menangkap radikal bebas yang masuk ke dalam tubuh (Mao et al., 2019). Peserta juga telah memahami dengan jelas bahwa bahan yang paling terasa digunakan dalam pembuatan permen jelly jahe adalah jahe emprit. Jahe dapat menghangatkan badan, dan dapat digunakan sebagai bahan campuran obat. Rimpang jahe mengandung energi, karbohidrat, serat, protein, sodium, besi, potasium, magnesium, fosfor, zeng, folat, vitamin C, vitamin B6, vitamin A, riboflavin dan niacin (Rahmani et al., 2014).

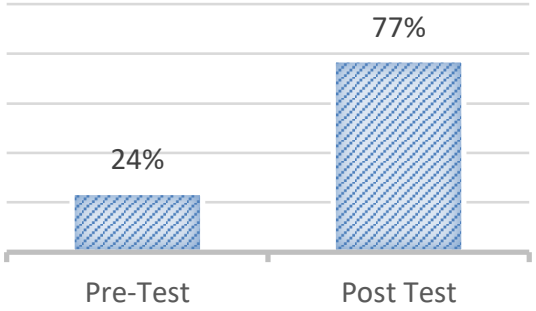

Gambar 3. Pengetahuan Peserta tentang Manfaat Jahe

Jahe diolah menjadi serbuk dan diaplikasikan pada pembuatan permen jelly jahe. Seluruh peserta sangat tertarik akan produk dan proses pembuatan permen jelly jahe yang mudah dicontoh dan diterapkan. Kegiatan selanjutnya adalah diskusi dan tanya jawab. Pertanyaan banyak diajukan seputar jahe dan permen jelly. Selanjutnya dilakukan pengisian angket untuk mengetahui pemahaman peserta tentang materi pelatihan dan proses pembuatan permen jelly jahe. Penyampaian materi tentang pengertian permen jelly jahe juga diberikan pada pelatihan ini. Permen jelly jahe yang termasuk ke dalam kategori permen lunak. Permen lunak adalah jenis permen berbentuk padat, dibuat dari gula, atau campuran gula dengan pemanis, dengan atau tanpa penambahan bahan pangan lain dan bahan tambahan pangan yang diijinkan, bertekstur lunak atau menjadi lunak jika dikunyah (Badan Standarisasi Nasional, 2008). Permen ini dibuat dari bahan dari tepung agar-agar atau tepung jelly dan dengan penambahan tepung jahe instan. Pembuatan tepung jahe instan telah diberikan pada kegiatan pelatihan sebelumnya dan diberikan juga video dalam bentuk link youtube agar masyarakat dapat mempelajarinya lebih lanjut. 
Pembuatan permen jelly jahe dapat dilakukan dengan du acara yaitu permen jelly jahe kering dan permen jelly jahe basah. Pada proses pembuatan permen jelly jahe kering dilakukan proses pengeringan dengan cara penjemuran dibawah cahaya matahari hingga lapisan luar permen mengering dan terbentuk kristal gula berwarna putih pada lapisan luar tersebut. Sebelum pelatihan hanya 19\% peserta yang pernah membuat permen jelly jahe. Setelah kegiatan pelatihan terjadi peningkatan jumlah peserta yang telah mencoba membuat permen jelly jahe menjadi 59\% (Gambar 3).

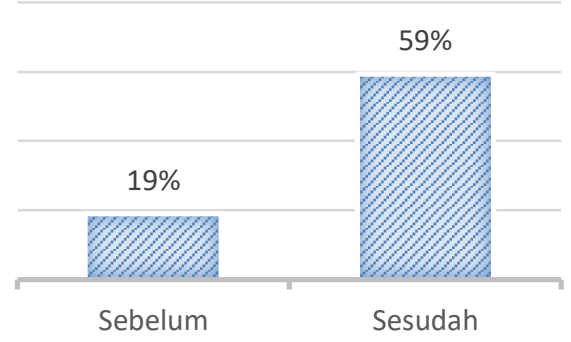

Gambar 4. Persentase Peningkatan Jumlah Peserta dalam Membuat Permen Jelly Jahe

Permen lunak jelly jelly memiliki tekstur dan kekenyalan tertentu, chewy yang bervariasi dari agak lembut hingga agak keras. Permen lunak jelly adalah permen bertekstur lunak. Pada kegiatan ini bahan pengenyal yang digunakan untuk memodifikasi tekstur sehingga menghasilkan produk yang kenyal adalah agar-agar. Hal ini sesuai dengan definisi yang menyebutkan bahwa penggunaan bahan pengenyal dapat digunakan pada pembuatan permen jelly (SNI 3547-2-2008). Hasil evaluasi terhadap pengetahuan peserta tentang bahan-bahan yang digunakan pada pembuatan permen jelly jahe, seluruh peserta dapat menjawab dengan tepat dan benar. Seluruh peserta menjawab sangat puas untuk pelaksanaan kegiatan pelatihan ini dan menyatakan bahwa produk permen jelly jahe skala rumah tangga ini layak untuk diproduksi dan dijadikan salah satu alternatif produk untuk usaha.

Penggunaan bahan alami yang memiliki fungsional tertentu pada kegiatan ini dilakukan untuk mengolah permen jelly. Permen jelly ini memiliki karakteristik mempunyai tekstur dan kekenyalan tertentu, chewy yang bervariasi dari agak lembut hingga agak keras (Lekahena, 2018). Berbagai ragam permen jelly dapat dijumpai dipasaran. Permen jelly yang pada kegiatan ini adalah permen jelly dengan penambahan sari jahe.

Jahe (Zingiber officinale) bisa dimanfaatkan sebagai bumbu masakan, bahan obat tradisional, atau dibuat minuman. Rimpang jahe digunakan sebagai ramuan obat luar untuk mengobati penyakit rematik, dan ramuan membuat minuman untuk mengobati masuk angin. Secara umum, jahe memiliki kandungan zat gizi dan senyawa kimia aktif yang berfungsi preventif dan kuratif. Dari segi nutrisi, jahe mengandung kalori, karbohidrat, serat, protein, sodium, besi, potasium, magnesium, fosfor, zeng, folat, vitamin $\mathrm{C}$, vitamin $\mathrm{B} 6$, vitamin $\mathrm{A}$, riboflavin dan niacin. Beberapa senyawa kimia aktif dalam rimpang jahe yang memiliki efek farmakologis terhadap kesehatan, antara lain: minyak atsiri dengan kandungan zat 
aktif zingiberin, kamfena, lemonin, borneol, shogaol, sineol, fellandren, zingiberol, gingerol, dan zingeron (Redi Aryanta, 2019).

Jahe merupakan salah satu bahan alam yang dapat ditambahkan dalam pembuatan permen lunak (Ridawati \& Alsuhendra, 2017) telah melaporkan pembuatan permen lunak lapis tipis dengan menggunakan sari terong belanda. Permen lapis tipis merupakan salah satu kategori permen lunak. Permen lunak itu sendiri adalah permen jelly yang bertekstur lunak. Permen ini diproses dengan penambahan komponen hidrokoloid seperti agar, gum, pektin, pati, karagenan, gelatin dan lain- lain. Bahan-bahan tersebut digunakan untuk memodifikasi tekstur sehingga menghasilkan produk yang kenyal (Badan Standarisasi Nasional, 2008).

Behan penting dalam pembuatan permen lainnya adalah gula pasir atau sukrosa. Sukrosa merupakan salah satu bahan yang ditambahkan pada proses pembuatan permen jelly. Penggunaan sukrosa pada pembuatan permen jelly memiliki fungsi untuk memberikan rasa manis, dan dapat pula sebagai pengawet, yaitu dalam konsentrasi tinggi menghambat pertumbuhan mikroba dengan cara menurunkan aktivitas air dari bahan pangan.

Bahan lain dalam pembuatan permen jelly pada kegiatan ini adalah agar-agar. Agar-agar merupakan produk utama yang dihasilkan dari rumput laut. Agar-agar memiliki kemampuan membentuk gel dan dimanfaatkan sebagai bahan pengemulsi (emulsifier), penstabil (stabilizer), pembentuk gel, pensuspensi, dan pelapis. Pada industri makanan agar-agar banyak dimanfaatkan sebagai bahan pembuat es krim, keju, permen, jelly, susu dan cokelat (Suparmi, 2013).

Pada pembuatan permen jelly, pemanasan sukrosa menyebabkan gula terurai menjadi glukosa dan fruktosa. Proses terurainya gula ini menyebabkan gula berubah menjadi gula invert. Sukrosa yang mengalami proses pemanasan selanjutnya akan mengalami proses kristalisasi gula. Gula kristal akan terbentuk dengan proses pemanasan lanjut atau proses pengeringan sehingga bagian luar dari permen akan mengeras. Pada proses pembuatan permen jelly dilaporkan bahwa tekstur kenyal pada permen dipengaruhi oleh kombinasi pemakaian gula sukrosa, isomalt (Sutejo et al., 2015) dan kombinasi sukrosa dan glukosa (Astuti et al., 2015). Pada kegiatan ini jenis gula yang digunakan adalah gula sukrosa tanpa kombinasi dengan jenis gula lainnya, sehingga untuk tahapan selanjutnya dan tahapan peningkatan skala produksi perlu dilakukan pelatihan lebih lanjut.

Pelaksanaan kegiatan pengabdian kepada masyarakat yang telah dilaksanakan dengan lancar, walaupun masih terdapat kendala selama kegiatan berlangsung, yaitu dibatasinya peserta kegiatan karena pelaksanaan kegiatan dilakukan pada waktu Pemberlakuan Pembatasan Kegiatan Masyarakat (PPKM) karena pandemic Covid-19, sehingga pelaksanaan praktik langsung tidak dilakukan.

\section{KESIMPULAN}

Simpulan dari kegiatan ini adalah kegiatan pelatihan pembuatan permen jelly jahe telah berlangsung dengan lancar dan dapat meningkatkan pengetahuan khalayak sasaran, egiatan diikuti peserta dengan sikap yang antusias, kebutuhan 
akan kegiatan yang meningkatkan pengetahuan dan ketrampilan peserta sangat diharapkan untuk dapat dilakukan secara berkala. Kendala yang dihadapi adalah terbatasnya ruang gerak pelaksanaan karena masih tingginya kasus pandemic Covid-19.

\section{UCAPAN TERIMAKASIH}

Terimakasih untuk Pendanaan Kegiatan ini melalui Dana POK BLU FT, UNJ tahun 2021

\section{DAFTAR PUSTAKA}

Astuti, S., Zulferiyenni, \& Yuningsih, N. N. (2015). Pengaruh Formulasi Sukrosa Dan Sirup Glukosa Terhadap Sifat Kimia Dan Sensori Permen Susu Kedelai. Jurnal Teknologi Industri \& Hasil Pertanian, 20(1), 25-37.

Badan Standarisasi Nasional. (2008). Standar Nasional Indonesia-Kembang Gula. kembang gula-Bagian 2:Lunak, 1.

Haryadi, R. N., Rojali, A., \& Fauzan, M. (2021). Sosialisasi Penggunaan Online Shop berbasis Website di UMKM Cimanggis. Jurnal Pengabdian Masyarakat Madani (JPMM), 1(1), 10-16.

Lekahena, V. N. J. (2018). Tingkat Kesukaan Konsumen Terhadap Produk Permen Jelly Rumput Laut Dengan Penambahan Konsentrasi Tepung Beras Ketan. Agrikan: Jurnal Agribisnis Perikanan, 11(1), 38. https://doi.org/10.29239/j.agrikan.11.1.38-42

Mashadi NS, Ghiasvand R, G, A., M, H., L, D., \& Mofid MR. (2013). AntiOxidative and Anti-Inflammatory Effects of Ginger in Health and Physical Activity: Review of Current Evidence. International Journal of Preventive Medicine, 4(1), 36-42.

Rahmani, A. H., Al Shabrmi, F. M., \& Aly, S. M. (2014). Active ingredients of ginger as potential candidates in the prevention and treatment of diseases via modulation of biological activities. International Journal of Physiology, Pathophysiology and Pharmacology, 6(2), 125-136.

Redi Aryanta, I. W. (2019). Manfaat Jahe Untuk Kesehatan. Widya Kesehatan, 1(2), 39-43. https://doi.org/10.32795/widyakesehatan.v1i2.463

Ridawati, \& Alsuhendra. (2017). Permen lapis tipis terong belanda.pdf. Prosiding Seminar Nasional Tahunan Matematika, Sains dan Teknologi. Universitas Terbuka.

Suparmi, A. S. (2013). Kajian Pemanfaatan Sumber Daya Rumput Laut Dari Aspek Industri dan Kesehatan. Gema Pustakawan, 1(1), 95-116.

Sutejo, V. I., Kusumawati, N., \& Widyawati, P. S. (2015). Pengaruh proporsi sukrosa dan isomalt terhadap sifat fisikokimia dan organoleptik soft candy susu kedelai. Jurnal Teknologi Pangan dan Gizi, 14(2), 83-88.

Yuangga, K. D., et al. (2021). Penyuluhan Management Creative Dalam Mendongkrak Inovasi Dan Memajukan Usaha Pada Sai Silver Bali. Jurnal Pengabdian Dharma Laksana, 4(1), 46-52. 